\title{
Transatlantica
}

Revue d'études américaines. American Studies Journal

\section{Cornelis A. van Minnen et Sylvia L. Hilton, eds., Teaching and Studying U.S. History in Europe : Past, Present and Future}

Amsterdam : VU University Press, European Contributions to American Studies Series 66, 2007.

\section{Marie Bolton}

\section{OpenEdition}

\section{Journals}

Édition électronique

URL : http://journals.openedition.org/transatlantica/3993

DOI : 10.4000/transatlantica.3993

ISSN : 1765-2766

Éditeur

AFEA

Référence électronique

Marie Bolton, « Cornelis A. van Minnen et Sylvia L. Hilton, eds., Teaching and Studying U.S. History in Europe: Past, Present and Future », Transatlantica [En ligne], 1 | 2008, mis en ligne le 28 juillet 2008, consulté le 29 avril 2021. URL : http://journals.openedition.org/transatlantica/3993 ; DOI : https:// doi.org/10.4000/transatlantica.3993

Ce document a été généré automatiquement le 29 avril 2021.

Transatlantica - Revue d'études américaines est mis à disposition selon les termes de la licence Creative Commons Attribution - Pas d'Utilisation Commerciale - Pas de Modification 4.0 International. 


\section{Cornelis A. van Minnen et Sylvia L. Hilton, eds., Teaching and Studying U.S. History in Europe : Past, Present and Future}

Amsterdam : VU University Press, European Contributions to American Studies Series 66, 2007.

\section{Marie Bolton}

1 Teaching and Studying U.S. History in Europe: Past, Present and Future is a book that will fascinate anyone interested either in American history as a European field of study or in European academia in general. It brings together the contributions of participants at the April 2005 meeting of the Roosevelt Study Center's Seventh Middelburg Conference of European Historians of the United States. As the title indicates, the authors' concerns are to present to readers the history of U.S. History in European universities, an assessment of its current status, and an indication of its future potential. The editors and contributors succeed thoroughly at this task. They also succeed in writing a captivating book in which readers learn about the visions that thirteen European countries have held historically of the United States, U.S. public diplomacy efforts in these countries during the Cold War, European reactions, and the post-Cold War situation. Readers are also given an insider's look at the malaise that currently plagues European academics experiencing budget restrictions and a considerable down-sizing of the humanities and social sciences, combined with radical structural changes designed to bring universities into conformity with new Europe-wide, internationalized standards.

2 The book is divided into two sections. The first is made up of two somewhat overlapping introductory chapters, analyzing the state of U.S. history in European universities and tracing the history of U.S. diplomatic efforts to promote American studies from the Cold War to the present. Immediately the reader becomes aware of tensions between the discipline of American history and the broader field of American 
studies. Even the book's title offers a clue to this. While the book itself is part of the European Contributions to American Studies series, it is entitled «Teaching and Studying U.S. History in Europe ", thus indicating its editors' focus on history.

While some countries claim a scholarly interest in the U.S. going back to the $18^{\text {th }}$ century, prior to 1945 most European universities offered few courses on U.S. history, and those that did were given by professors of modern and contemporary history, located in history departments largely devoted to the history of their own countries. (In an important parallel given the original location of most American studies courses in language and literature departments, before 1945 few English departments offered courses on American literature, focusing instead on British literature.) All this changed after 1945 and the expansion of U.S. public diplomacy as part of Cold War efforts to "win the hearts and minds » of Europeans. Not only were U.S. officials determined to combat European cultural elitism regarding American popular culture, but teaching young Europeans about American history was seen as a way of fighting the appeal of communism in Europe. Although American policy was carried out perhaps less « carefully and deliberately » than one author claims (48), it certainly was the primary catalyst for the spectacular growth in American studies in Europe from 1945 to 1989. The U.S. Information Agency financed American Studies organizations (founded mostly by historians), conferences, and archival and library collections in Europe; U.S. foundations established university chairs in American history and American studies; and the Fulbright Program made possible a regular and lively exchange of American and European students and academics. The effects of U.S. policy coincided with a homegrown postwar increase in interest in American studies as Europeans sought to explore the culture and history of one of the world's superpowers. In 1954, the Salzburg Seminar hosted the inaugural meeting of the European Association for American Studies, bringing together existing national American Studies associations and encouraging the creation of many more.

4 This history is traced as well in the 13 individual country reports that make up the book's second section, with one contributor making the essential connection between the period of generous U.S. financial and material assistance and the vast expansion of most European universities in the "absolutely exceptional phase of the 'mass university' " (169) from the late 1960s to the early 1980s. This golden age is now definitely over. During the 1990s, funding was cut for the State Department's Bureau of Educational and Cultural Affairs as well as for U.S. Embassies in general, and the U.S. Information Agency was entirely abolished. Since 2005, what scant funding remains has gone to countries considered more strategically important, such as Indonesia and India. Although hopes are expressed that with the withdrawal of American support, a " consciously post-Cold War 'New American Studies' will emerge in Europe » (61), many contributors to the second section of the book express fears of a bleak future for American history and American studies in the current climate of budget cuts. In addition, as American studies itself is an American phenomenon transplanted to Europe and supported and financed at least initially with American aid, with a reduction of the academic pie, always existing tensions between American historians and their colleagues in American studies have increased. This creates the dramatic urgency animating the book's second section.

5 Each country report follows the same pattern : first, a review of that country's interest in U.S. history through the Cold War period, second an overview of the recent and 
current state of U.S. history in its universities, and third, an evaluation of its future potential. The discussions of the place of U.S. history in the cultural landscape of Europe (or rather of Austria, Denmark, France, Germany, Britain, Ireland, Italy, the Netherlands, Norway, Poland, Russia, Spain, and Sweden) provide a fascinating glimpse into the intellectual history of these countries in relation to U.S. history. Prior to 1945, the angle of interest in the U.S. varied according to local experience, for instance in the writing of republican constitutions, U.S.-bound emigration, or imperial competition. Ideology came into play especially in monarchies and empires seeking to downplay the early republican experience in America, as in France and Britain, while in other countries such as Ireland up to quite recently higher education in general was severely restricted. But as one author points out, it was «World War II which shattered the complacent assumption that American history could be ignored» (133).

During and after the Cold War, as detailed by the authors, local situations again dictated university conditions, course offerings, and research opportunities. The contributors provide considerable food for thought about academic freedom (east and west, ideological and financial) and the impact of specific countries' histories on the study of the U.S. Polish and Soviet scholars, for instance, long worked under ideologically restrictive conditions (unfortunately the discussion of Germany is focused uniquely on West Germany with no mention either of conditions in East Germany or of the impact of re-unification), as did scholars in Franco's Spain. In Great Britain, a "special relationship » developed between British and American academics that led to «British scholars [coming] to be accepted by Americans as members of their own academic community ", with one historian writing «I... consciously tried to make my work indistinguishable from that of U.S.-based historians » $(142,138)$. The May 1968 explosion was critical in opening up the university structurally to studies of the U.S. in France, as were the massive 1970s student enrollments in Italy. In each setting, the role of U.S. diplomacy varied, as did its timing, moving east to Poland and Russia in the 1960 s and 1970s, and financially almost abandoning all of Europe after the 1980s. Some of the authors explore the contradictory aspects of teaching courses often critical of the U.S. in a diplomatic context in which the U.S. had been engaged in fighting antiAmericanism. Others offer suggestions about the usefulness of American studies for the development of their own national or European identity. The authors also dwell on European unification and its impact on attitudes towards the U.S. and university conditions in general. All of this makes for rich and informative reading, pitched to the insider, but accessible as well to the general reader.

7 Academic rivalries and ever-present worries about perennial budget cuts and on-going as well as impending reforms (both national and European) underlie the 13 country reports. Tellingly, each of these chapters is entitled « The Study of [U.S. or American] History ", rather than American Studies, what one contributor calls « a description that has often been used to cover any academic interest in the United States " (156). Nine out of the thirteen authors identify themselves as historians: five as modern or contemporary historians specializing in the U.S. ; four as historians of the U.S. (one of these more specifically as U.S.-Latin American); and four as American Studies specialists (one co-authored chapter is here counted once for the discipline its represents). These scholars work variously in history departments; in English Departments, sometimes called Anglo-American Studies Departments ; or, more rarely in specialized American Studies programs or departments. The authors specify that their assessments are based on published materials, professional experience, and input 
from colleagues, rather than strictly quantified data. Academic standards in the treatment of evidence are as rigorously observed as for any topic of study. What remains problematic is the widely differing ways in which these scholars treat the considerable amount of teaching and research on U.S. history taking place outside of traditional history departments. Divergent disciplinary training and identity seem to form the basis of a general mistrust between practitioners of what several contributors refer to as "pure » history and what is viewed as a rather non-disciplinary American studies, although there are exceptions to this view. The editors cite one British scholar's claim that "those departments that focus more on literature, culture, and media studies have more young white middle-class female students than departments that focus more on politics, international relations, and geography » and «the heavier female student demand... influences hiring policies ». With a surprising lack of analysis given this extraordinary statement, the editors simply question whether this trend is Europe-wide and might result in a shift from «hard " to "soft » themes in American studies (33). They do not consider the wide range of variables influencing the demographics of both students and academics that might provide an alternative explanation to gender shifts in enrollments and hiring.

The authors of the country reports locate variously the origins of U.S. history teaching and research in their countries : in seven countries it emerged in history departments ; in three countries it began both in history and English departments; and in three countries in English departments. The American studies professional associations established in the 1950s or 1960s, were to act, as one contributor explains, « as pressure groups for Americanists of all disciplines » (135). Although in the early years, certainly oiled by generous American financial aid, members of history and English departments worked together in the interest of American studies and developed widely varied curricula and research interests, over time fissures appeared in a never cohesive structure. The country reports make clear not only differences of national culture, but of the views adopted by historians and American studies specialists.

Of the three American studies scholars, one explains that French history departments, dominated by national history, "were slow in accepting these new colleagues " and « it would take aspiring Americanists from English departments a whole decade to gain a modicum of recognition and respectability... By the 1980s the courses offered to English majors in American Studies covered a great variety of domains, not only literature and cultural studies, but also U.S. social, political, diplomatic, and economic history " (103-4). This throws into question the hard/soft, male/female dichotomy suggested by the editors, since French "'civilizationists' have long based their teaching, like historians, on the study of historical documents... [and] are forming with dual expertise the young scholars of the twenty-first century-a promising generation equally versed in the social sciences and the subtleties of the English language » (106). Nonetheless, a "malaise» remains, behind which "usually lurks the perennial issue of scientific legitimacy, not infrequently raised by self-styled 'professional' historians from history departments » (105-6). The Norwegian situation seems less fractious, with « American Civilization" programs administered by departments of modern languages, but offering a wide array of courses in U.S. history and cultural studies. At the University of Oslo, for example, these are taught by four U.S.-trained PhDs, two in American Studies and two in history (202). Nonetheless, even this contributor has a claim to make with regard to historians and « emphasizes the role played by the American Studies sectorbased mainly in English departments-over the part played by university history 
departments ». This « is primarily due to the fact that the former institutions... have constituted the hub of the American Studies movement and have carried the main burden, especially in the field of teaching, offering courses with a broad American culture dimension informed by historical methods and perspectives as well » (206).

From the historians' corner as well, sharp distinctions are drawn. One historian, while praising their " ongoing relationship of fruitful cooperation and exchange », separates "historians and literary scholars", as having "two distinctive professional and institutional trajectories » within Italian universities (160). Subsequently, his country report focuses on "U.S. history in the strictest sense of the term and leave[s] aside American Studies " (159). In Russia, another historian states that in the growing number of American studies programs, " historians usually are not invited to teach... courses " in "Civilization " and "Culture ", and he deplores the "growing differences in standards and approaches to teaching U.S. history [that] have created a fragmentation of the field which is difficult to overcome because of the lack of cooperation among those involved» (228). An Austrian historian argues that although «the cultural element [in American studies programs] has been significantly strengthened, ... there has been little progress towards an interdisciplinary integration of historical, political, and socioeconomic aspects into a truly comprehensive area study» (69). The historians' position has partly developed in reaction to what one Polish cultural historian applauds as the attitude among " young historians, often with degrees in English, oblivious to the constraints of conventional history they never knew as students. The have the edge over their traditionally educated fellow-historians by familiarity-often fascination-with recent critical theory, literary theory and cultural studies, which they eagerly apply to the study of historical sources » (217). In many countries, generational and disciplinary elements seem to be the most influential in creating an increasing separation between the two groups of Americanists. The institutional climate and the current financial reductions in most European social science programs must be taken into account as well. Overall there seems to be a trend toward the restriction of interdisciplinary programs such as American studies, and a retrenchment of scholars into what the editors call their «professional scholarly identity » as defined by « ministerial norms and institutional structures.... [E]ven when their teaching or institutional affiliation is in multidisciplinary programs and departments, it seems unlikely that historians trained as such will renounce or stray very far from the theory, the methods and the aims of their specific discipline » (41).

11 Historians from various countries also describe a sense of rejection from American study colleagues within professional associations. One scholar describes in Germany the "exclusionary tactics of the representatives of American literature and culture ", (127) and in the Austrian association, historians have always existed " regrettably » as " merely a marginal and largely uninfluential group» (69). Another historian laments the discipline-specific specialized vocabulary of literary and cultural studies as leading to communication problems among Americanists in general. In most countries, while maintaining membership in American studies associations, historians have founded, with a tangible sense of relief, their separate professional organizations devoted to the study of U.S. history. They also hold historians' minority-status meetings when participating in the large annual American studies conferences. The ways in which all these tensions play out in various countries differs greatly, as illustrated in these academics' vivid accounts. 

currently face institutional obstacles as well as disciplinary ones. The disappearance of U.S. financial assistance has to some degree been overcome by the maturity of the American Studies associations and the institutional integration of U.S. history and American studies into European university systems. However, the new standards and structures imposed upon (or adopted by, depending on the country and the institution) European universities as part of the Bologna Plan and the European Credit Transfer System in scheduling and grading, have often coincided with a dramatic decrease in financial support for the humanities and social sciences. As a result, in many countries English departments have been replaced by the equivalent of modern language departments, which then absorb area studies, with the U.S. as one area under study. These departments, along with history departments, find themselves with reduced budgets as national and local policies increasingly encourage universities to downsize the social sciences in favor of currently popular technical and applied studies. Individual scholars and departments respond in various ways to counter what are generally seen as negative forces. A variety of suggestions are made, including placing the study of the U.S. into that of the "Atlantic World", or alternatively the «Americas». Yet while some scholars encourage the opening of area studies, others predict a return to traditional academic disciplines. One Spanish historian points out the two basic problems: "One refers to definition: Is history/civilization/culture merely background for language and literature, or is it a separate and equally valued field ? The other pertains to the relation between departmental structure and officially recognized disciplines or fields of study, as well as to the resulting allotment of resources, tenure-track positions, and responsibility for teaching courses on U.S. history and culture " (244). In spite of the difficult budgetary issues, there is a great diversity in the outlook of scholars, ranging from institutional fatigue and a sense of impending doom, to a great confidence in the institutional future of both U.S. history and American studies.

Ultimately, this book reflects diversity. The diversity among scholars of various and sometimes quarrelling disciplines, yet joined by their passion for the study of the U.S.. The diversity of national experience, history, and culture, as reflected in institutions and in attitudes toward the U.S. The diversity of individual views reflected in these carefully researched but somewhat personal reflections on the study of U.S. history. All these bring to this book interesting and thought-provoking observations, making it a pleasure to read.

14 Now for just a few caveats, barely worthy of mention. The book could have benefited from a tighter editing process in terms of a sprinkling of mispellings, grammatical errors, mispunctuations, and repetitions, as well as a curious indenting style. This reader was surprised not to find any reference to the American Historical Organization's La Pietra Report (NY : New York University, 2000), nor to other various efforts on the part of Americans and Europeans to unite their scholarship. In the 1970s for instance, leading historians of that quintessentially internationalist topic, working class history, came together in a series of meetings and conferences in Europe out of which came Dirk Hoerder's influential book, American Labor and Immigration History, 1877-1920s : Recent European Research (Urbana : University of Illinois Press, 1983). Related to this work, Hoerder founded the Journal of International Working Class History, still going strong. Surprisingly, especially given their strong European scholarly backing, there is 
no mention of these publications. As several historians make observations about the relationship between U.S.-based and European scholars, the lack of mention, especially of the admittedly self-important La Pietra Report, perhaps reflects the maturity of U.S. history in Europe and its ability to function on its own terms. This speaks highly for the potential of scholars, in the words of the editors, to "simultaneously close ranks in traditional disciplines and seek new academic alliances, in order to navigate the perilous shoals of the market-oriented convergence in European higher education " (45).

INDEX

Thèmes : Recensions 